\title{
Risk Perception and Bottled Drinking Water Consumption in Istanbul City
}

\author{
Gurdal Kanat* \\ Yildiz Technical University, Faculty of Civil Engineering, Department of Environmental Engineering, 34220, Esenler, Istanbul, Turkey \\ Received: 07/06/2017, Accepted: 21/09/2017, Available online: 24/10/2017 \\ *to whom all correspondence should be addressed: e-mail: gkanat@gmail.com
}

\section{Abstract}

Parallel to the increase in public concern about the safety of drinking water globally, the demand for bottled water has increased in almost every country. Although tap water is significantly cheaper than bottled water, consumers concerned about the safety of tap water. They still prefer the bottled water despite several checks implemented in tap water networks. The present paper aims to discuss network water quality in the city of Istanbul, Turkey and to present the findings on a related survey conducted by the authors. The survey was conducted with the participation of 980 individuals living in different districts in Istanbul and the findings were assessed to determine the public perception about tap water quality and bottled water consumption especially after the experienced years of drought and water quality concerns. Findings demonstrated that several individuals never drink tap water and certain individuals do not utilize tap water at all. It was found that only $4 \%$ in the surveyed group drink tap water without hesitation. Based on survey findings, the abovementioned group was mainly among the lowest income group in the sample. When purchasing bottled water, several individuals preferred the well-known brands. It was found that the most significant reasons for preferring bottled water were the nice taste of the bottled spring water, which was perceived not to exist in tap water. It was concluded that drinking water treatment facilities and regulations are required to cater the future quality demands. Furthermore, it was determined that adequate inspections and controls on network water are necessary.

Key words: Bottled water, drought, network water quality, risk perception, water consumption.

\section{Introduction}

The increasing number of studies on environmental problems and growing awareness on these problems due to easy access to information intensified the public concern about water pollution, and tap water filter promotion campaigns amplified individuals' concerns on water quality globally (Guler 2007; Bereskie et al., 2017). It was reported that the tap water filter sales became a $\$ 1.4$ billion annual industry even in 1996 according to data of Water Quality Association (Virgin, 1996). Although several individuals consider the aesthetic qualities of drinking water (appearance and taste) more, they are also concerned about pathogens, generally under the influence of media news. In recent years, the media has reported several cases of contamination due to the increasing number of infections and the number of related research has also increased. A famous hospital in the US has reported that bacteria, viruses, and parasites can cause many diseases related to drinking water and can infect any bodily organ (CHW, 2007). There are some other examples in the literature. Giardia lamblia, a tiny parasite that can live in the intestines of humans and all animals, is recognized as one of the most common waterborne diseases in the US, today.

In several countries, there was an increase in public concern for drinking water quality, and thus, bottled water consumption increased as well. There were several studies conducted on tap water quality and digestive system infections related to tap water use and the results of such studies were discussed in the media extensively. Among the common problems experienced in developing countries, lack of quality water networks, inefficient water management and also similar problems such as water outages could be listed. Thus, it could be argued that there is a higher water contamination risk in developing countries.

The worldwide bottled water industry had a large budget (US\$ 35 billion per year) and expanding rapidly (BWW, 2001; Ragusa and Crampton, 2016). The US consumption of bottled water in 2008 was estimated to be around 33 billion litters, or 104 liters per person (Hu et al., 2011). Similarly, demand of bottled water showed a sharp rise from annual 30 million liters in 1980 to 810 million liters in 1996 in the UK (Ferrier, 2001).

Bottled water was firstly used in the Italian market after 1970 and consumption per person has shown a 4 times rise (47 to 192 liters) between 1980 and 2008 (Carlucci et al., 2016). Annual increase in Australian bottled water consumption in 2004 was estimated to be approximately $20 \%$ by 2008 (as value of $\$ 236$ millions), but in fact this high forecast was surpassed by a significant margin. Bottled water industry reached to $\$ 627$ million value in 2007 and 
this value means tripling the amount of 2004 (Datamonitor, 2004; Ragusa and Crampton, 2016).

Although, tap water is cheaper than bottled water, consumers are concerned about its quality despite several controls conducted in water networks. However, there are not sufficient numbers of studies about the safety of bottled water, especially in developing countries where control and sampling systems are poorer. In one of the few related studies, microbial quality was investigated and changes were found in water quality after storage conditions (Armas and Sutherland, 1999). In another study, bacteria or fungi contamination was observed in $40 \%$ of the samples (IRC, 2004).

However, bottled water sales in almost every country increase continuously (Feliciano, 2014; Ragusa and Crampton, 2016). Some water markets were much more popular to promise, such as in Asian and Pacific markets (Ferrier, 2001). Population and engineering capacities of the countries affect the water market. Bottled water consumption in Asia was a third of global consumption in 2013. As the most populous countries and having low quality network water, India and Pakistan were taken into account as greater market potential when compared to European markets. Bottled water consumption increased in these developing countries while high tap water quality and use of filtration products in European countries resulted in a limited growth in bottled water industry (Langley, 2013). One of the highest increases was in the US. Bottled water industry surpassed the previous year's sales figures by $6.2 \%$ in 2012 and $\$ 11.8$ billion revenues were generated. So, the US was the largest market in the world and bottled water industry became the second biggest beverage sector in the US by sales volume (IBWA, 2016). It should be noted here that IBWA's stated mission is to serve the corporate members by increasing water sales volume as a healthy choice for hydration and a better lifestyle (IBWA, 2015). However, the toxicity of plastic products used in water bottles, and environmental impact of the discarded bottles received less attention than the market growth rate (Ragusa and Crampton, 2016; Fischer et al., 2016; Wright et al., 2013). A research on the ecological impacts of bottled water demonstrated that more than 460,000 barrels of oil were consumed for transportation of bottled water annually and huge amount of greenhouse gases (around 60,000 tons) were produced and, unfortunately only less than $40 \%$ of the bottles could be recycled (Coolaustralia, 2014).

There are several studies and papers in scientific literature on bottled water industry and risk perception of the public about drinking water that ranged from technical aspects to social behavior research (Platikanov et al., 2017; Fragkou and McEvoy, 2016; Gungor-Demirci et al., 2016; Carlucci et al., 2016; Dias and Bernardes, 2016; Ragusa and Crampton, 2016). However, it could be argued that it is still not easy to find clear conclusions on the topic. For example, in Australia, research in sociology about bottled water have concentrated specifically on risk perception and public health concerns related to fluoridation, desalination of water or risk perceptions on recycled water, but related cultural studies were only few (Ragusa and Crampton, 2016). Globally theoretical or undetailed scientific studies fail to explain individuals' choose meaningfully for bottled water consuming (Brei and Tadajewski, 2015).

In contrast, only a few scientific studies can be found about Istanbul and Turkey. It is very important to discover the water quality perception of the people, not only for water authorities but also for environmentalist, at least to prevent the ever increasing amount of the plastic waste. It is also questionable that current international standards may not be suitable to supply drinkable quality network water (such as, taste of water). In this study, results of a survey are presented. In order to determine the perception of the public on drinking water quality and to analyze the bottled water consumption in Istanbul, a survey was prepared and conducted with 980 individuals including students of our university and their families or neighbors living in different urban districts in Istanbul and the results were evaluated.

\section{Water Quality and Risk Perception in the Past Years}

Istanbul is a metropolitan city, where approximately 13 million people live. High population increase and unplanned urbanization have caused a major water management issue in the city. The water demand in the city is around 1.1 billion $\mathrm{m}^{3}$ /year and is estimated to be twice as much within the following 20 years (ISKI, 2016).

Between 1985 and 1994, drought conditions were combined with mismanagement of the local water authority and it caused severe restrictions of water availability on some days. After the dry years experienced in 1990s, the water consumption habits of the urbanites changed considerably. During water shortages, water could not be supplied to many areas of the city on some days especially in the summer months, which was a significant personal hygiene risk. Water shortage days were as long as 15-20 days periods. During the drought, the mayor (a Medical Doctor) strongly warned the public that the water network was not reliable and drinking water should be boiled for health reasons.

Before the years of drought, the demand for small water bottles (0.5-1.5 L) was generally low. Only few individuals consumed local spring water sold in $3 \mathrm{~L}$ glass containers. These customers were usually in high-income level and preferred bottled water for purity and nice taste as per the advertising campaigns of a few major manufacturers. After the extensive shortages and negative health effects of the poor quality tap water were discussed in the media, water fill (selling) stations emerged in certain Istanbul neighborhoods. In the 1994, the number of such stations has already reached to 3000 (Erikli, 2007). Although demand was high, hygiene standards of the stations became the subject of a continuous media debate.

Most of these stations were closed and the manufacturers were obliged to attach a holographic sticker to water bottles for sale. Furthermore, back in those years, smallscale treatment equipments were used at homes for water purification. Several manufactures advertised these activated carbon adsorption or UV treatment appliances to 
treat the network water at homes. However, due to the high prices of these appliances, the hardships related to their home installation, and the unaccustomed unique taste of the treated water, the demand for these devices was generally low. Finally, when the serious tap water pollution was over, these appliances started to disappear from homes.

Advancement of the infrastructure through engineering work that was initiated by the new Istanbul mayor improved the tap water quality within a few years after 1994. In contrast with the previous years, water authority announced several times that tap water quality was good and reliable. During that time, ISKI published detailed water quality analysis results both weekly and monthly on its official web site (ISKI, 2016).

Biggest cities in Turkey, firstly the most populated Istanbul city, account for the largest share of bottled water consumption in the country due to poor tap water networks (mainly taste of water) that fail to provide the needs of increasing population. In Turkey, during the last decades, bottled water using volume was very low. However, the annual consumption increased to around 4 million tons in 2001 (Milliyet, 2007). The financial revenues of the bottled water market were US\$ 165 million. As seen in Table 1, the volume of water market in Turkey reached 11.1 billion liters in 2015 (SUDER, 2016).

Some more details about water quality and risk perception in Istanbul are given in the Annex)

\section{Materials and Methods}

A random sample of individuals living in Istanbul participated in the survey. Questionnaires were distributed to nine hundred and eighty students attending Yildiz Technical University (YTU) in Istanbul. The students were selected from different departments, and were requested to invite their family members, neighbors, and/or friends to participate in the survey. However, it was stipulated that a single student could not submit more than 3 questionnaires. A total of 910 completed questionnaires were returned, providing a response rate of $93 \%$. Survey form was not long and complex, including only six main multiple-choice questions. Thus, it was possible to obtain a high response rate.

The sample student group represented almost all districts of Istanbul and a range of household characteristics (number of children, level of education, etc.). Demographics of the sample population are presented in Table 1. When compared to the municipal demographics and 2000 census results, it could be observed that the sample represented the population. The participants of the survey and urban residents had similar age distribution.

Only volunteering subjects participated in the survey. And they were free to withdraw from the research at any time. Majority of the participants were willing to fill the survey form and some even provided detailed responses that were utilized in qualitative analysis. A pilot scheme was conducted with the first student group to test the comprehensibility of the questions in the survey. Each participant was asked to provide demographical information such as name, phone number and address for control purposes; however they were assured that personal information will be kept confidential. When all subjects completed the questionnaire, 50 participants were randomly selected to confirm the accuracy of the provided information by phone calls or e-mail. As expected, certain participants did not respond to questions about their family income in the survey form. The forms of such participants were included in statistical analysis, if the remaining questions were fully answered in the form. Statistical software was utilized to conduct statistical analyses. Statistical significance level was accepted as 0.05 .

\subsection{The design of the survey form}

Questions related to municipal tap water network and bottled water consumption were included in the questionnaire. The fundamental questions about tap water included questions aimed to obtain information whether the participants used tap water for drinking or utilized it for cooking or to brew tea, in essence only after boiling it. Questions related to bottled water consumption focused on participants' intentions when purchasing bottled water. Supplementary questions about municipal water network and bottled water were also included in the questionnaire. Their perception about the quality of tap water was inquired with the question whether the participants used tap water for drinking or utilized it for cooking or to brew tea. The survey form aimed to determine the preferences of the participants for the following questions:

1. Do you use tap water for drinking?

2. Do you boil tap water before drinking?

3. Do you use tap water for preparing tea or coffee?

4. If the water authority would announce periodically water quality reports and would state that the water is clean enough, do you prefer to drink tap water?

5. Which one do you prefer; bottled, filtered or other type of purified water for drinking?

6. What do you prefer when buying bottled water? 
Table 1. The volume of water market in Turkey.

\begin{tabular}{|c|c|c|c|c|c|c|c|c|c|}
\hline \multirow[b]{2}{*}{ Volume $\left({ }^{*} 10^{6}\right.$ liters $)$} & \multicolumn{9}{|c|}{ Years } \\
\hline & 2007 & 2008 & 2009 & 2010 & 2011 & 2012 & 2013 & 2014 & 2015 \\
\hline Total production & 8.1 & 8.7 & 9.0 & 9.5 & 9.9 & 10.3 & 10.3 & 10.7 & 11.1 \\
\hline $20 \mathrm{~L}$ bottles & 6.0 & 6.3 & 6.3 & 6.4 & 6.5 & 6.5 & 6.2 & 6.33 & 6.4 \\
\hline PET, smaller bottles & 2.1 & 2.4 & 2.8 & 3.1 & 3.4 & 3.8 & 4.2 & 4.4 & 4.7 \\
\hline Consumption/capita, L & 115 & 122 & 124 & 128 & 133 & 135 & 135 & 138 & 143 \\
\hline Increase, \% & - & 7 & 3 & 6 & 4,2 & 3,1 & 1,2 & 3,8 & 3,9 \\
\hline Total export, tons & - & 103,920 & 123,364 & 128,430 & 147,226 & 173,470 & 199,137 & 250,866 & 275,953 \\
\hline Total export, US\$ & - & $19,000,000$ & $19,663,246$ & 20,089927 & $24,817,287$ & $27,644,100$ & $31,704,910$ & $42,186,950$ & $46,405,643$ \\
\hline
\end{tabular}

Table 2. Demographic characteristics of the survey population in the study.

\begin{tabular}{|c|c|c|c|}
\hline & & $\mathbf{n}$ & $\%$ \\
\hline \multirow[t]{2}{*}{ Gender } & Male & 470 & 48 \\
\hline & Female & 440 & 52 \\
\hline \multirow{3}{*}{ Age } & Under 25 & 210 & 23 \\
\hline & $25-40$ & 380 & 42 \\
\hline & 40 \& over & 320 & 35 \\
\hline \multirow{3}{*}{ Monthly household income in US\$ } & $<700$ & 410 & 51 \\
\hline & $700-1400$ & 330 & 41 \\
\hline & 1400 \& over & 65 & 8 \\
\hline
\end{tabular}




\section{Results and Discussion}

The study results and distribution of responses among different groups are presented in annexed tables. It can be observed that several participating individuals do not drink tap water in any time. It is also found that certain individuals do not use tap water for cooking and for brewing coffee or tea. When buying bottled water, several individuals preferred renowned brands that were produced by large corporations. The majority of survey participants do not drink tap water even though they boil it, but they used it for cooking or brewing coffee or tea. Thus, in general, the participants stated that the main problem of the water network quality was the taste of tap water. Boiling the tap water is the conventional and easiest method to remove biological contaminants in the tap water to obtain drinking water. Individuals living in developing countries usually drink the tap water after boiling it due to the perception that tap water network is unsafe for drinking. However, the cost of boiling large volumes of water could be high. In a report of the World Bank, it is estimated that $1 \%$ of Jakarta's GDP was spent on boiling of water (Jalan et al., 2003).

In order to determine the factors effective on the participants' decision about not drinking the tap water, their concerns about its quality or its taste, they were asked whether they would drink if the water authority states officially that the water was good to drink. The number of the participants who selected the 'Yes' answer for this question were higher but still lower than those who said they would still use it for preparing tea or coffee. The factor behind that decision was again the taste of water. In a recent study, Ragusa and Crampton (2016) also reported that $77 \%$ of interviewees in Australia and New Zealand considered the quality of drinking water, but interestingly, although $64 \%$ drank bottled water, only $28 \%$ of interviewees believed that bottled water was better than tap water and $63 \%$ thought that drinking bottled water as a waste of money.

Participants were also asked to choose the type of water they consume, i.e. bottled or other processed commercial water. Number of participants who preferred bottled water was lower when compared to other questions, but probably due to a misunderstanding about the question. Some participants thought that bottled water meant those sold only in small containers, such as 1 or 0.5 liters plastic bottles but not higher volumes. In Turkish, bottled water in larger containers has a different name.

In the last section, the participants were asked to select the factors that affected their choice of bottled water. Majority of the participants preferred quality or a particular brand, while only a few chose the price as a reason for their preference. Low-income respondents preferred lowerpriced bottled water brands. Some brands are more expensive than others because their content is supposed to be supplied from high quality resources. Moreover, most participants considered that it was difficult to maintain a near zero risk water network in a rapidly growing city. They had the knowledge that the water authority monitors that main tap water network regularly, however the participants also knew that tap water might be contaminated due to older pipes or contaminated water storage tanks, which are located at the residences. Although, Istanbul Water Administration (ISKI) has regularly conduct quality analyses of water and announce those reports on the official web site and that network water quality was better than international standards, such as WHO, etc (ISKI, 2008; ISKI, 2016), individuals show a clear evidence that they, at least, do not like the taste of the tap water. Similarly a recent study demonstrated that several consumers (63\%) believed that bottled water was convenient and safer than other sources of drinking water in Galle district, Sri Lanka (De Rekha et al, 2016).

Furthermore, due to the fact that the network water quality was frequently the topic of political debate in the past, certain individuals considered that several political statements were exaggerated and disregarded the reports about the quality of tap water networks. Thus, comprehensive statements and analyses conducted by impartial parties such as academicians or civil servants are required to increase public awareness. It could be concluded that commercial bottled water and home water treatment appliances are preferred. This is mainly due to the tap water quality that is far from the taste found in commercial spring water (or treated water).

Cost of bottled water in Istanbul is $250-700$ times more expensive than tap water (for $1 \mathrm{~L}$ ). For comparison, it might cost up to 1000 times more than tap water in certain other countries (WWF, 2004). Thus, most individuals consume it only for drinking water, but use tap water for other purposes such as tea, coffee, cooking, etc. Although it is more expensive, bottled water consumption has doubled in the past 20 years and reached to 130 liters per year per inhabitant in Paris and 80 liters in Istanbul in 2004. However, this practice also increases plastic consumption and waste output. World Wildlife Fund reported that as more as 1.5 million tons of plastic are used for water bottling (WWF, 2004), which is a substantial problem especially in touristic areas where recycling facilities are inadequate such as Nepal (Himalayan Times, 2004). Furthermore, a report explains that annually a quarter of the 89 million liters of bottled water globally are exported to other countries from their origin country (WWF, 2004). Emissions during the transportation of those products in and across the countries also contribute to the problem of worldwide air pollution.

The bottled water demand has continuously increased in the past years. Although increase rates vary remarkably related to the countries' characteristic, it is a global trend. For instance, bottled water consumption per capita increased 20\% every year in New Zealand between 1997 and 2004. In Eastern European countries and in the AsiaPacific region, the increase in demand was about $13 \%$ per year. Similarly the consumption rate increased approximately $6 \%$ in a year in the USA and Western Europe between 1997 and 2004. (Fragkou and McEvoy, 2016; Espinosa-García et al., 2015). This might be considered as a paradox as tap water quality standards have also constantly rehabilitated in the last years in many countries, 
including Turkey. The most important question, then, is why increasing number of people decide to pay more for bottled water. This question was studied by several researchers (Saleh et al., 2001). In reality, people do not think very detailed that bottled water is "better" or "worse" than tap water. In some studies, bottled and tap water analysis are compared and some results concluded that some bottled water are better in quality, but it is not correct in every case (Lalumandier and Ayers 2000; Ragusa and Crampton, 2016). Quality of both resources is still an important debate in the media and scientific literature (Uzundumlu et al., 2016; Van Der Linden, 2013; GungorDemirci et al., 2016). Some studies point out that tap water is monitored with more strict standards and more frequently analyzed, while it is not such that for water bottling. It is also same in Istanbul. Water authority report that analysis of the water were done weekly. However, some experts expressed that bottled water is treated better, and/or it is less exposed to contamination during production and distribution (Doria et al., 2005).

In Turkey, water presented in $5 \mathrm{~L}$ plastic bottles is retailed the most in several cities and cost around 3-6 TL. In the last years, some water brands in Turkey sell water in $20 \mathrm{~L}$ glass bottles, but mainly not to prevent the plastic pollution problem. The main idea is to obtain higher quality water which is less polluted by contact with the plastic container due to the perception that glass is a better container. However, glass bottle is much more expensive and the market share of the product is very low.

\subsection{Cross analysis of the results}

Statistical analyses were conducted to assess the responses provided by the participants for each survey question. The chi-square test was used to compare each question statistically. To determine the tap water drinking rates, participants were asked to choose one of the three choices (yes, no or occasionally) in the first question. It was determined that there was no statistically significant difference between the participant responses based on gender variable in the first question $\left(p=0.336 \chi^{2}=2.181\right.$. This value was less than the critical value of 5.991 at $\alpha=0.05$ significance level with 2 degrees of freedom). However, as expected, the bottled water utilization rate was higher for the individuals with high income. Thus, a higher proportion of the high income individuals choose the 'No' answer (\%97). Furthermore, there was no statistically significant difference between the age groups $\left(p=0.703, \chi^{2}=2.177\right.$, $\mathrm{df}=4$ ), although younger participants drank tap water at a slightly lower rate. Similarly, Ragusa and Crampton (2016) found that bottled water consumption vary particularly related to gender, while men and younger individuals purchased more bottled water. However, since only $13 \%$ described bottled water as a 'reliable' product, it was observed that participants predominantly mistrust water suppliers, even though they consume bottled water for its taste or convenience, and $13 \%$ labeled bottled water a 'bad' plastic product with negative impact on the environment or public health, supporting the institutional and political trends about banning bottled water. In another study, De Rekha et al. (2016) determined that education level of the water consumers significantly influences their perception for the most of the parameters significance. The consumers with higher education levels considered price as an insignificant factor. Moreover, consumers with low education levels considered price as a significant factor. However, individuals with less than average monthly income do not care about the cost of bottled water, while people with higher income considered the brand name as important, while individuals with a lower income did not care about the brand name.

The second question aimed to determine the risk perception since it is common knowledge that boiling the water, milk, etc. could remove the pathogens in these substances. Despite this fact, lower than expected number of participants was found to drink boiled tap water. Similarly, there was no difference based on gender, while there were fewer "Yes" responses in the female group $\left(p=0.293, \chi^{2}=2.454, d f=2\right)$. There was no statistically significant difference between the age groups as well $\left(p=0.128, \chi^{2}=4.115, d f=2\right)$. In the first and second questions, the rate of ' $\mathrm{No}$ ' answers given by individuals with low income was not high (\%3 and \%7, respectively) in the study group, but the majority of the participants chose the 'occasionally' choice (\%90 and \%86, respectively). In question three, the participants were asked whether they used tap water to brew tea or coffee. The main factor differentiating the responses given by the participants to this question was the sense of taste; normally, the taste of water cannot be differentiated when used in cooked foods. Thus, percentage of using the boiled tap water was higher in every group. There was no statistically significant difference between the responses based on gender $\left(p=0.997, \chi^{2}=0.046, d f=2\right)$ and age groups $(p=0.663$, $\left.\chi^{2}=2.396, \mathrm{df}=4\right)$. Garcia-Rubio et al., (2016) also found in their study that consumers accept quality of tap water inversely proportional with the education level and income.

Study results demonstrated that several individuals never drank tap water and some abstain from using it for any purpose at all. They use only bottled water or water treated in home purification systems. Several individuals preferred to choose popular brands manufactured by large corporations when buying bottled water. It was found in the present study that most participants gave a poor rating to Istanbul's tap water. The main reason for using tap water alternatives seems to be the differences in taste. Only $4 \%$ of the participants drank tap water without hesitation. Based on the findings of the present study, these respondents mainly belonged to the group with the lowest income. Level of awareness on problems related to drinking water, presence of contamination and the duration of experienced issues generally affected drinking water risk perception.

\section{Conclusions}

Study results demonstrated that several individuals participating in the study never drank tap water and several individuals did not utilize it at all. Only $4 \%$ of the participants drank tap water without hesitation. According 
to the survey, these respondents were mainly among the low-income group. Several participants preferred the wellknown brands manufactured by prominent corporations when buying commercial bottled water. These individuals preferred to consume bottled water due to the low quality tap water and the superior taste of the spring water.

Results of the present study may contribute to the decisions of policymakers. They should do the best in planning to manage adverse socio-ecological consequences related to bottled water. The future hosts, similarly, several challenges about public health concerns and maintaining the public confidence. Changes in water authority management and drinking water treatment practices are necessary to meet new demands and future regulations, at least concerning the problem of taste. Transferring the water from mountainous areas is not a sustainable solution. Life cycle assessment studies may help to find sustainable alternatives. Water Administration may provide further treatment systems to supply better drinking tap water using certain methods. Furthermore, new and sufficient inspection and control regulations need to be asserted in network maintenance.

\section{References}

Armas A.B. and Sutherland J.P. (1999), A survey of the microbiological quality of bottled water sold in the UK and changes occurring during storage, International Journal of Food Microbiology, 48, 59-65.

Bereskie T., Rodriguez M.J. and Sadiq R. (2017), Drinking Water Management and Governance in Canada: An Innovative PlanDo-Check-Act (PDCA) Framework for a Safe Drinking Water Supply, Environmental Management, DOI 10.1007/s00267017-0873-9

Brei V. and Tadajewski M. (2015), Crafting the market for bottled water: a social praxeology approach, European Journal of Marketing, 49(3/40), 327-349.

BWW (2001). Portal for the bottled water industry, Bottled Water Web Team, From web site: www.bottledwaterweb.com

Carlucci D., De Gennaro B. and Roselli L. (2016), Competitive strategies of Italian bottled water industry: evidence from a hedonic analysis, Rivista di Economia Agraria, 71(1), 292-304.

CHW (2007). Viruses, bacteria and parasites in the digestive tract. From web site of Children's Hospital of Wisconsin (www.chw.org/display/PPF/DoclD/22819/ router.asp), May 2007.

Coolaustralia (2014). Research from web site: Coolaustralia.org

Datamonitor (2004, May). Bottled water in Australia. In Reference code:0125-0016, Datamonitor, NY.

De Rekha E.P.R., Bandara W.D.L.S and Ellawala C. (2016), Bottled Drinking Water: Evaluation Of Consumption Tendencies And Water Quality, Proceedings of the Undergraduate Research Symposium on Recent Advances in Civil Engineering, Department of Civil and Environmental Engineering, University of Ruhuna.

Dias P. and Bernardes A.M. (2016), Carbon emissions and embodied energy as tools for evaluating environmental aspects of tap water and bottled water in Brazil, Desalination and Water Treatment, 57(28), 13020-13029, DOI: 10.1080/19443994.2015.1055815
Doria M.F., Pidgeon N. and Hunter P.R. (2005), Perception of tap water risks and quality: a structural equation model approach, Water Science and Technology, 52(8), 143-149.

Erikli (2007) Erikli Bottled Water Company Report, web page: www.erikli.com.tr

Espinosa-García A.C., Díaz-Ávalos C., González-Villarreal F.J., ValSegura R., Malvaez-Orozco V. and Mazari-Hiriart M. (2015), Drinking water quality in a Mexico City University community: perception and preferences, Eco-Health, 12(1), 88-97.

Feliciano J. (2014, 17 February). Bottled Water in 2014: Packaging, branding, and the search for value. Retrieved from Euromonitor.com

Ferrier C. (2001), Bottled water: understanding a social phenomenon, $A M B I O$ : A Journal of the Human Environment, 30(2), 118-119.

Fischer E.K., Paglialonga L., Czech E. and Tamminga M. (2016), Microplastic pollution in lakes and lake shoreline sediments a case study on Lake Bolsena and Lake Chiusi (central Italy), Environ. Pollut., 213, 648-657.

Fragkou M.C. and McEvoy J. (2016), Trust matters: Why augmenting water supplies via desalination may not overcome perceptual water scarcity, Desalination, 397, $1-8$

Himalayan Times (2004). The Himalayan Times News. From web site: $\quad$ www.thehimalayantimes.com, on 10th June.

Hu Z., Morton L.W. and Mahler R.L. (2011) Bottled water: United States consumers and their perceptions of water quality, Int J Environ Res Public Health, 8(2), 565-578.

Garcia-Rubio M.A., Tortajada C. and González-Gómez F. (2016), Privatising water utilities and user perception of tap water quality: Evidence from Spanish urban water services, Water Resour Manag, 30(1), 315-329.

Guler C. (2007), Evaluation of maximum contaminant levels in Turkish bottled drinking waters utilizing parameters reported on manufacturer's labeling and government-issued production licenses, J. Food Compos Anal, 20, 262-272.

Gungor-Demirci G., Lee J., Mirzaei M. and Younos T. (2016), How do people make a decision on bottled or tap water? Preference elicitation with nonparametric bootstrap simulations, Water and Environment Journal, doi:10.1111/wej.12181

IBWA (2015). International Bottled Water Association, Retrieved from:

http://www.bottledwater.org/about\#sthash.ronBXC5c.dpuf

IBWA (2016). Bottled water market, International Bottled Water Association, Retrieved from:

http://www.bottledwater.org/economics/bottledwatermarket

IRC (2004). International Water and Sanitation Centre. From web site: www.irc.nl (23rd November).

ISKI (2008). Monthly Water Quality Reports, Istanbul Water and Wastewater Administration.

ISKI (2016). Monthly Water Quality Reports (2008-2016), Istanbul Water and Wastewater Administration web page: http://www.iski.istanbul/web/tr-TR/su-kalite-raporlari.

Jalan J., Somanathan E. and Chaudhuri S. (2003), Awareness and the demand for environmental quality: drinking water in urban India, discussion papers in economics, Indian Statistical Institute, Delhi Planning Unit, September, New Delhi, India. 
Lalumandier J.A. and Ayers L.W. (2000), Fluoride and bacterial content of bottled water vs tap water, Archives of Family Medicine, 9, 246-250.

Langley S. (2013). April 29. Bottled water could become soft drinks leader by 2015, Retrieved from: http://www.ausfoodnews.com.au/2013/04/29/bottledwater-could-become-soft-drinks-leaderby-2015.html

Milliyet (2007). Milliyet Newspaper, economy news. From web site: www.milliyet.com.tr, on $18^{\text {th }}$ February.

Platikanov S., Hernándezb A., Gonzálezc S., Cortinac J.L., Taulera R. and Devesab R. (2017), Predicting consumer preferences for mineral composition of bottled and tap Water, Talanta, 162, 1-9.

Ragusa A.T. \& A. Crampton (2016) To Buy or not to Buy? Perceptions of Bottled Drinking Water in Australia and New Zealand, Hum Ecol., 44:565-576, DOI 10.1007/s10745-0169845-6

Uzundumlu A.S., Fakioglu O., Kokturk M. and Temel T. (2016), Using of Municipal Mains Water for Drinking Water in an Urban Region under Uncertain Economic, Social, Cultural and Health Impacts, Ethno Med, 10(2), 178-185.

Saleh M., Ewane E., Jones J. and Wilson B. (2001), Chemical evaluation of commercial bottled drinking water from Egypt, J. Food Compos. Anal., 14(2), 127-152.

SUDER, 2016. Packaged Water Producers Association's web page, www.suder.org.tr/sektor.html

Virgin B. (1996). Filters can improve taste and smell, guard health. Seattle Post-Intelligencer. From web site: www.chron.com (www.chron.com/content/houston/interactive/special/ water/08/water/ water-filtration-tues.2-1.html)

Van Der Linden S. (2013), Exploring beliefs about bottled water and intentions to reduce consumption: the dual-effect of social norm activation and persuasive information, Environ. Behav., 47, 526-550.

Wright S.L., Thompson R.C. and Galloway T.S. (2013), The physical impacts of microplastics on marine organisms: a review, Environ. Pollut., 178, 483-492.

WWF (2004). Report of WWF Living Waters Campaign, From web site: www.wwf.org 


\section{-Annex-}

\section{Water Quality and Risk Perception in Istanbul}

Istanbul metropolitan city is the most populated city in Turkey and the province hosts approximately 14 million people and nearly $50 \%$ of the industrial establishments in the country. The population increase rate in Istanbul is still higher than the national average, which is 25 per thousand. This high population increase and unplanned urbanization cause a major water management issue in the city. The water demand in the city is around 1.1 billion m3/year and is estimated to be twice as much within the following 20 years (ISKI, 2016). Explosive urbanization after 1970s and the $14 \%$ annual inbound migration rate in early 1980 s forced Istanbul to improve and renovate its tap water supply system. In the last decades, water authority was invested US\$ 3.6 billion to improve, expand and renovate the water supply and also wastewater systems in the city (ISKI, 2016).

During the 1980s, about 400 million m3 of water was supplied to Istanbul annually, but this amount still fell short of the urban demand. By 1999, this amount had increased to 900 million $\mathrm{m} 3$ per year, although the supply decreased 20\% during the dry seasons. In 1990 and 1994, as a result of insufficient water reserves, certain neighborhoods received water only once a week (in certain districts, even less than that).

\section{Drought Years}

Between 1985 and 1994, drought conditions caused severe restrictions of water availability. In the following years, due to investments to meet the tap water demand, the water supply and demand were almost equal under the new management in the water authority by 2000 . Although, water reserves and network capacity were increased with some engineering works, precipitation decreased in 2007 and again the mayor advised that people should use less water. Also, the municipality attempted to provide water from much farther resources in the eastern parts of the province. Hence, the distance that the city water was hauled subsequently increased. The drinking tap water was provided from 16 reservoirs and lakes in the province. Main drinking water reservoirs of the city are located in the northern forested regions.

Dry years in 1990s altered the water consumption habits considerably. During water shortages, water could not be supplied to many areas of the city. Water shortage days were as long as 15-20 days periods. This was mainly due to the financial and administrative problems experienced in Istanbul Water and Wastewater Administration (ISKI), which is the responsible authority for the municipal water network. During the drought, the mayor strongly warned the public to boil the water for health reasons. His words were justified due to the risk of contamination risk in the tap water network induced by water outages and the risk of groundwater leaching (penetration). In addition, there was pollution in the largest urban water reservoir, Omerli Watershed. Unplanned and unauthorized urbanization and uncontrolled discharges, as well as insufficient wastewater system, resulted in the contamination of the said reservoir with household and industrial discharge. However, there are no detailed research conducted on the pollution in this reservoir and its potential risks for public health.

After 1994, ISKI utilized certain auxiliary methods to reduce the water deficit including artificial cloud seeding and shipping water from other centers using sea vessels. However, these methods were proven to be expensive, hard and the shipment consumed a great deal of time, and shrinked the municipal budget for future investments.

Before the drought years, the demand for bottled water was low. After the extensive shortages of tap water, water stations emerged in Istanbul after 1994. The municipal government owned the initial "Akdamla" (WhiteDrop) brand stations. The spring water was transported to these stations using water trucks from nearby mountains and the water was sold in 10-20 L plastic containers, or generally in re-usable (plastic) containers that were self-supplied by customers. Containers were filled using (a type of) fuel pumps in these stations. However, hygiene standards of the stations became the subject of a continuous media debate. Also, some media outlets claimed that network water or mixed water (purified or non-purified tap water) was sold in bottles instead of spring water due to the lack of official control. In the first years, it was almost a free market without adequate control.

The Department of Health only controlled the hygiene conditions at the filling stations, but the water quality was mainly neglected. Only when a new by-law was enacted concerning commercial spring water production by the Ministry of Health (18 October 1997, no. 23144), most of these stations were closed within a year and the manufacturers were obliged to fill the bottles with a holographic sticker for sale and open. Customer supplied containers were no longer allowed. However, this decision was objected by the Association of Water Station Owners claiming that thousands of individuals could lose their jobs when the water stations would be closed. The association predicted that more than 6000 water stations were operating in Istanbul only and the total investments in the industry was 15-20 million Turkish Liras (1 US\$:1.3 TL in 1998). Today, there are no water-selling stations, and only $20 \mathrm{~L}$ polycarbonate plastic bottles filled by automatic machines at central facilities are common in the market. These bottles are sold in many cities and cost around 7-15 TL (Turkish Lira). In Turkey, large percent of the consumed bottled water is non-carbonated. It is much more preferred by the consumers, while (natural) carbonated water is consumed less, only for its mineral content.

\section{New Water Authority Management}

In 1994, water shortages even had an impact on the municipal elections. The incumbent mayor lost the elections. The new mayor appointed an environmental engineering professor as ISKI General Director. Until the new administration, studies on the quality of water resources were conducted, however only a few engineering studies were done. The new ISKI director 
organized new resources, decreased water leakages and improved the engineering abilities in the organization. Due to the professional management and thanks to abundant rain, the urban water network started to provide tap water 24 hours every day. However, at that period of a few years, bottled water demand has increased considerably as several prominent manufacturers have established dealership networks all around the city. Furthermore, the water safety issues remained to be the topic of discussion in the media. Thus, ISKI management published of $E$. coli analyses on tap water, conducted in different urban neighborhoods, however the results were below the World Health Organization (WHO) safety standards. During that time, ISKI published detailed water quality analysis results both weekly and monthly on its official web site (ISKI, 2016).

In these years, a different argument was raised. After the years of the drought, several buildings purchased and installed 3-5 ton plastic water tanks to store the water on building roofs to be utilized during water shortages. It was practical to collect water overnight in these tanks, when the water pressure is high in the network. But water authority announced that water quality in the tanks could deteriorate in a few years due to insufficient maintenance, and stated that these should be maintained regularly. Today, these tanks are not installed in many homes since the water cuts are rare in Istanbul. After these efforts, ISKI announced that the tap water was safe to consume at homes without a need for any further treatment.

Boiling water is a conventional and efficient method to remove any biological contaminants in drinking water. Similarly, mayor of Istanbul advised to boil the tap water before drinking in Istanbul in 1989. However, advancement of the infrastructure through engineering work that was initiated by the new Istanbul mayor improved the tap water quality within a few years (after 1994). In contrast with the previous years, water authority announced several times that tap water quality was good and reliable. During this time, advertising campaigns featuring renowned pop stars were conducted to ensure the population that the tap water was safe to drink.

\section{Bottled Water Increase}

In Turkey, during the last decades, bottled water using volume was very low. In 2001, the financial revenues of the bottled water market were US\$ 165 million. Biggest cities in Turkey, firstly the most populated Istanbul city, account for the largest share of bottled water consumption in the country due to poor tap water networks that fail to provide the needs of increasing population. High migration number of people from small cities and rural areas and mismanagement of urbanization have caused to bad water quality in the cities. In several Turkish cities, individuals preferred to drink tap water during the past decades, at least when they are thirsty in summer months. However, this has been greatly altered due to the deteriorating perceptions about the network water quality and increased concerns about pollution, predominantly in metropolitan cities.
In Turkey, the regulation (in February 2005) defined bottled water as 'spring' or 'drinking' non-carbonated water sold in bottles for consumption. According to the Ministry of Health, there are 226 facilities in Turkey where drinking water is bottled. Majority (167) of these facilities produce bottled natural spring water, while 31 bottle mineral water, 20 bottle drinking water and 7 facilities bottle processed (purified) drinking water (Milliyet, 2007). Only one facility is recorded to bottle processed spring water. Five large corporations have a $85 \%$ share of the total bottled water market. The abovementioned facilities are generally located on mountainous areas near the major cities of Istanbul, Bursa, Izmir and Sakarya, where the largest percentage of bottled water consumption takes place. Annual consumption increased to around 4 million tons, in spite of an economic crisis that was prevalent in the country in 2001. In 2006, the market share of bottled water industry increased by $10 \%$ when compared to previous years and the capital value of the industry was around US\$350 million the same year. The total production amount was 7.8 billion and total exports worth US\$19 million (Milliyet, 2007). In 2015, total exported packaged water was 276,000 tons and the total turnover was $\$ 46,405,643$ (SUDER, 2016). 


\section{Cross Analysis Tables of the Survey}

Table 1. Percents of response choices for question one.

\begin{tabular}{ccccccccccc}
\hline & GROUPS & Yes & C \%* & R \%* & No & C \% & R \% & Sometimes & C \% & $\mathrm{R} \%$ \\
\hline \hline \multirow{3}{*}{ Gender } & Male & 19 & 0,53 & 0,04 & 145 & 0,48 & 0,31 & 306 & 0,53 & 0,65 \\
& Female & 17 & 0,47 & 0,04 & 156 & 0,52 & 0,35 & 267 & 0,47 & 0,61 \\
& Total & 36 & 1,00 & 0,04 & 301 & 1,00 & 0,33 & 573 & 1,00 & 0,63 \\
\hline \multirow{3}{*}{ Income** } & $>1800$ & 0 & 0 & 0 & 63 & 0,24 & 0,97 & 2 & 0 & 0,03 \\
(YTL) & $900-1800$ & 2 & 0,06 & 0,006 & 191 & 0,72 & 0,58 & 137 & 0,27 & 0,415 \\
& $<900$ & 30 & 0,94 & 0,07 & 12 & 0,05 & 0,03 & 368 & 0,73 & 0,90 \\
& Total & 32 & 1,00 & 0,04 & 266 & 1,00 & 0,33 & 507 & 1,00 & 0,63 \\
\hline \multirow{4}{*}{ Age } & $<25$ & 7 & 0,19 & 0,03 & 71 & 0,23 & 0,34 & 132 & 0,23 & 0,63 \\
& $25-40$ & 13 & 0,36 & 0,03 & 121 & 0,40 & 0,32 & 246 & 0,43 & 0,65 \\
& $>40$ & 16 & 0,44 & 0,05 & 110 & 0,37 & 0,34 & 194 & 0,34 & 0,61 \\
& Total & 36 & 1,00 & 0,04 & 301 & 1,00 & 0,33 & 573 & 1,00 & 0,63 \\
\hline
\end{tabular}

* $\mathrm{C}=$ Column, $\mathrm{R}=\mathrm{Row}, * *$ Sum was less than total (910) because some respondents were not answered the income choice.

Table 2. Percents of response choices for question two.

\begin{tabular}{ccccccccccc}
\hline & GROUPS & Yes & C \%* & R \%* & No & C \% & R \% & Sometimes & C \% & $\mathrm{R} \%$ \\
\hline \hline \multirow{4}{*}{ Gender } & Male & 19 & 0,51 & 0,04 & 144 & 0,48 & 0,31 & 307 & 0,54 & 0,65 \\
& Female & 18 & 0,49 & 0,04 & 156 & 0,52 & 0,355 & 266 & 0,46 & 0,605 \\
& Total & 37 & 1,00 & 0,04 & 300 & 1,00 & 0,33 & 573 & 1,00 & 0,63 \\
\hline \multirow{4}{*}{ Income } & $>1800$ & 0 & 0 & 0 & 63 & 0,22 & 0,97 & 2 & 0 & 0,03 \\
(YTL) & $900-1800$ & 5 & 0,15 & 0,015 & 191 & 0,68 & 0,58 & 134 & 0,27 & 0,405 \\
& $<900$ & 28 & 0,85 & 0,07 & 28 & 0,10 & 0,07 & 354 & 0,72 & 0,86 \\
& Total & 33 & 1,00 & 0,04 & 282 & 1,00 & 0,35 & 490 & 1,00 & 0,61 \\
\hline \multirow{4}{*}{ Age } & $<25$ & 4 & 0,12 & 0,02 & 74 & 0,23 & 0,35 & 132 & 0,24 & 0,63 \\
& $25-40$ & 13 & 0,38 & 0,034 & 127 & 0,40 & 0,334 & 240 & 0,43 & 0,632 \\
& $>40$ & 17 & 0,50 & 0,05 & 115 & 0,36 & 0,36 & 188 & 0,34 & 0,59 \\
& Total & 34 & 1,00 & 0,04 & 316 & 1,00 & 0,35 & 560 & 1,00 & 0,62 \\
\hline
\end{tabular}

* $\mathrm{C}=$ Column, $\mathrm{R}=\mathrm{Row}$

Table 3. Percents of response choices for question three.

\begin{tabular}{ccccccccccc}
\hline & GROUPS & Yes & C \%* & R \%* & No & C \% & R \% & Sometimes & C \% & R \% \\
\hline \hline \multirow{3}{*}{ Gender } & Male & 121 & 0,51 & 0,26 & 65 & 0,52 & 0,14 & 284 & 0,52 & 0,60 \\
& Female & 116 & 0,49 & 0,26 & 60 & 0,48 & 0,14 & 264 & 0,48 & 0,60 \\
& Total & 237 & 1,00 & 0,26 & 125 & 1,00 & 0,14 & 548 & 1,00 & 0,60 \\
\hline \multirow{3}{*}{ Income } & $>1800$ & 4 & 0,02 & 0,06 & 57 & 0,50 & 0,88 & 4 & 0,01 & 0,06 \\
(YTL) & $900-1800$ & 53 & 0,25 & 0,16 & 55 & 0,48 & 0,17 & 222 & 0,46 & 0,67 \\
& $<900$ & 152 & 0,73 & 0,37 & 2 & 0,02 & 0,00 & 256 & 0,53 & 0,62 \\
& Total & 209 & 1,00 & 0,26 & 114 & 1,00 & 0,14 & 482 & 1,00 & 0,60 \\
\hline \multirow{4}{*}{ Age } & $<25$ & 51 & 0,21 & 0,243 & 30 & 0,24 & 0,143 & 129 & 0,24 & 0,614 \\
& $25-40$ & 94 & 0,39 & 0,247 & 52 & 0,41 & 0,137 & 234 & 0,43 & 0,616 \\
& $>40$ & 93 & 0,39 & 0,29 & 45 & 0,35 & 0,14 & 182 & 0,33 & 0,57 \\
& Total & 238 & 1,00 & 0,26 & 127 & 1,00 & 0,14 & 545 & 1,00 & 0,60 \\
\hline
\end{tabular}

* C=Column, R=Row 
Table 4. Percents of response choices for question four.

\begin{tabular}{|c|c|c|c|c|c|c|c|c|c|c|}
\hline & GROUPS & YES & C \%* & R \%* & NO & $\mathrm{C} \%$ & $\mathrm{R} \%$ & Sometimes & $\mathrm{C} \%$ & $\mathrm{R} \%$ \\
\hline \multirow{3}{*}{ Gender } & Male & 66 & 0,52 & 0,14 & 64 & 0,51 & 0,14 & 340 & 0,52 & 0,72 \\
\hline & Female & 62 & 0,48 & 0,14 & 62 & 0,49 & 0,14 & 316 & 0,48 & 0,72 \\
\hline & Total & 128 & 1,00 & 0,14 & 126 & 1,00 & 0,14 & 656 & 1,00 & 0,72 \\
\hline \multirow{4}{*}{$\begin{array}{c}\text { Income } \\
\text { (YTL) }\end{array}$} & $>1800$ & 0 & 0 & 0 & 62 & 0,55 & 0,95 & 3 & 0,01 & 0,05 \\
\hline & $900-1800$ & 10 & 0,09 & 0,03 & 50 & 0,44 & 0,15 & 270 & 0,47 & 0,82 \\
\hline & $<900$ & 102 & 0,91 & 0,25 & 1 & 0,01 & 0,00 & 307 & 0,53 & 0,75 \\
\hline & Total & 112 & 1,00 & 0,14 & 113 & 1,00 & 0,14 & 580 & 1,00 & 0,72 \\
\hline \multirow{4}{*}{ Age } & $<25$ & 24 & 0,19 & 0,11 & 37 & 0,29 & 0,18 & 149 & 0,23 & 0,71 \\
\hline & $25-40$ & 51 & 0,40 & 0,134 & 54 & 0,43 & 0,142 & 275 & 0,42 & 0,724 \\
\hline & $>40$ & 51 & 0,40 & 0,16 & 36 & 0,28 & 0,11 & 233 & 0,35 & 0,73 \\
\hline & Total & 126 & 1,00 & 0,14 & 127 & 1,00 & 0,14 & 657 & 1,00 & 0,72 \\
\hline
\end{tabular}

* C=Column, R=Row

Table 5. Percents of response choices for question five.

\begin{tabular}{|c|c|c|c|c|c|c|c|}
\hline & GROUPS & YES & C \%* & R \%* & NO & $\mathrm{C} \%$ & $\mathrm{R} \%$ \\
\hline \multirow{3}{*}{ Gender } & Male & 186 & 0,50 & 0,40 & 284 & 0,53 & 0,60 \\
\hline & Female & 187 & 0,50 & 0,425 & 253 & 0,47 & 0,575 \\
\hline & Total & 373 & 1,00 & 0,41 & 537 & 1,00 & 0,59 \\
\hline \multirow{4}{*}{$\begin{array}{c}\text { Income } \\
\text { (YTL) }\end{array}$} & $>1800$ & 60 & 0,18 & 0,92 & 5 & 0,01 & 0,08 \\
\hline & $900-1800$ & 170 & 0,52 & 0,52 & 160 & 0,34 & 0,48 \\
\hline & $<900$ & 100 & 0,30 & 0,24 & 310 & 0,65 & 0,76 \\
\hline & Total & 330 & 1,00 & 0,41 & 475 & 1,00 & 0,59 \\
\hline \multirow{4}{*}{ Age } & $<25$ & 130 & 0,35 & 0,62 & 80 & 0,15 & 0,38 \\
\hline & $25-40$ & 154 & 0,41 & 0,41 & 226 & 0,42 & 0,59 \\
\hline & $>40$ & 90 & 0,24 & 0,28 & 230 & 0,43 & 0,72 \\
\hline & Total & 374 & 1,00 & 0,41 & 536 & 1,00 & 0,59 \\
\hline
\end{tabular}

* C=Column, R=Row

Table 6. Percents of response choices for question six.

\begin{tabular}{ccccccccccc}
\hline & GROUPS & YES & C \%* & R \%* & NO & C \% & R \% & Sometimes & C \% & R \% \\
\hline \hline \multirow{3}{*}{ Gender } & Male & 144 & 0,48 & 0,31 & 305 & 0,53 & 0,65 & 21 & 0,57 & 0,04 \\
& Female & 156 & 0,52 & 0,35 & 268 & 0,47 & 0,61 & 16 & 0,43 & 0,04 \\
& Total & 300 & 1,00 & 0,33 & 573 & 1,00 & 0,63 & 37 & 1,00 & 0,04 \\
\hline \multirow{3}{*}{ Income } & $>1800$ & 8 & 0,03 & 0,12 & 57 & 0,11 & 0,88 & 0 & 0 & 0 \\
(YTL) & $900-1800$ & 105 & 0,44 & 0,32 & 222 & 0,42 & 0,68 & 1 & 0,03 & 0,00 \\
& $<900$ & 128 & 0,53 & 0,31 & 252 & 0,47 & 0,62 & 30 & 0,97 & 0,07 \\
& Total & 241 & 1,00 & 0,30 & 531 & 1,00 & 0,66 & 31 & 1,00 & 0,04 \\
\hline \multirow{4}{*}{ Age } & $<25$ & 47 & 0,17 & 0,22 & 157 & 0,26 & 0,75 & 6 & 0,17 & 0,03 \\
& $25-40$ & 102 & 0,38 & 0,27 & 270 & 0,45 & 0,71 & 8 & 0,22 & 0,02 \\
& $>40$ & 122 & 0,45 & 0,38 & 176 & 0,29 & 0,55 & 22 & 0,61 & 0,07 \\
& Total & 271 & 1,00 & 0,30 & 603 & 1,00 & 0,66 & 36 & 1,00 & 0,04 \\
\hline
\end{tabular}

* C=Column, $\mathrm{R}=$ Row 